\title{
Interactions of Temperature and Photoperiod Determine Expression of Repeat Flowering in Strawberry
}

\author{
Emma Bradford, James F. Hancock, and Ryan M. Warner ${ }^{1}$ \\ Department of Horticulture, Michigan State University, A288 Plant and Soil Sciences Building, East \\ Lansing, MI 48824
}

\begin{abstract}
Additional INDEX words. Fragaria ×ananassa, flowering, heat tolerance, short-day, day-neutral, everbearing, photoperiodism

ABSTRACT. Strawberry (Fragaria $\times$ ananassa) cultivars vary greatly in the expression of remontancy, or repeat flowering. To more clearly define the roles of temperature and daylength in flowering control of strawberry, the nonremontant cultivar Honeoye, and two remontant genotypes classified as day-neutral, 'Tribute' and an elite clone of Fragaria virginiana ssp. virginiana, RH 30, were grown at 14, 17, 20, 23, 26, or $29^{\circ} \mathrm{C}$, under a short (9 h) or long (16 h) photoperiod. Differential flowering responses of genotypes across temperature and photoperiod treatments resulted from variation in 1) the photoperiod-insensitive permissive temperature range for flowering, 2) photoperiodic requirement if temperature exceeded the photoperiod-insensitive range, and 3 ) the rate of development of axillary meristems. The photoperiod-insensitive temperature range varied from 14 up to $20^{\circ} \mathrm{C}$ for 'Honeoye', $23{ }^{\circ} \mathrm{C}$ for $\mathrm{RH} 30$, and $26^{\circ} \mathrm{C}$ for 'Tribute'. When temperature exceeded the photoperiod-insensitive range, 'Honeoye' and $\mathrm{RH} 30$ required short days for flowering, while 'Tribute' required long days. Flowering of 'Honeoye' lagged behind 'Tribute' and RH 30 by about 84 days in treatments where flowering occurred. These results indicate that temperature and floral initiation/development rate strongly influence the expression of remontancy, and that screening genotypes for day neutrality alone is unlikely to result in the development of robustly remontant cultivars.
\end{abstract}

Strawberry cultivars traditionally have been classified into photoperiodic response groups for flowering. June bearers are defined as facultative short-day (SD) plants (Darrow, 1936), everbearers are classified as long-day plants (LD) (Darrow and Waldo, 1934), and photoperiod-insensitive varieties are defined as day neutral (DN) (Bringhurst and Voth, 1978). However, early on, Darrow (1936) described the influence of temperature on flower initiation in strawberry, indicating the potential difficulty in photoperiodic classification of cultivars. Flower induction of SD types can occur under any photoperiod if the temperature is cool enough, generally $<15{ }^{\circ} \mathrm{C}$ (Guttridge, 1985). Similar interactions of temperature and photoperiod have been reported for everbearing varieties, responding as qualitative LD plants at high temperatures $\left(>25^{\circ} \mathrm{C}\right)$, quantitative LD plants at lower temperatures $\left(10\right.$ to $\left.25^{\circ} \mathrm{C}\right)$, and $\mathrm{DN}$ at temperatures below $10{ }^{\circ} \mathrm{C}$ (Nishiyama and Kanahama, 2000; Sønsteby and Heide, 2007). At high temperatures, inhibition of flowering in SD types is observed even under short photoperiods (Ito and Saito, 1962), and flowering of DN and LD types also decreases at high temperatures (Durner et al., 1984; Heide, 1977; Serçe and Hancock, 2005a). In a controlled environment study, Durner et al. (1984) reported inconsistent effects of photoperiod on the flowering of two SD cultivars grown under different temperature regimes, further suggesting the inadequacy of classifying cultivars into photoperiodic response groups to predict multiple flowering cycles without consideration for temperature effects.

Strawberry cultivars exhibit considerable variation in the degree of repeat flowering, referred to as remontancy. The same

Received for publication 5 Nov. 2009. Accepted for publication 4 Feb. 2010. ${ }^{1}$ Corresponding author. E-mail: warnerry@msu.edu. genotype may be remontant in some parts of the United States, but not in others (Durner et al., 1984), or may exhibit remontancy some years, but not others in the same location. Because cultivars that produce multiple crops during the summer can extend the growing season for farmers, understanding the genetic basis of repeat flowering has been an active area of investigation (Ahmadi et al., 1990; Powers, 1954; Serçe and Hancock, 2005a; Shaw, 2003; Sugimoto et al., 2005; Weebadde et al., 2008). Unfortunately, the genetic basis of remontancy remains poorly understood, with inconsistent inheritance ratios reported for different populations using the same genetic source of remontancy (Hancock et al., 2002; Serçe and Hancock, 2005a; Shaw, 2003; Shaw and Famula, 2005) or in different trialing locations using the same clonally propagated segregating populations (Hancock et al., 2002; Weebadde et al., 2008).

The objectives of this work were to determine the effects of temperature and photoperiod on the expression of remontancy of 'Honeoye' and 'Tribute', previously described as SD and $\mathrm{DN}$, respectively; and another genetic source of remontancy, RH 30, an elite clone of Fragaria virginiana ssp. virginiana, previously classified as DN (Hancock et al., 2002). The results of this work will expand our knowledge of the environmental control of this trait and allow us to identify appropriate screening environments to breed remontant cultivars.

\section{Materials and Methods}

During Summer 2007, after spring flowering had ceased, field-grown plants with developing runner plants of Fragaria Xananassa 'Tribute' [bred in Maryland and released 1981 (Draper et al., 1981)] and 'Honeoye' [bred in New York and 
released 1979 (Brooks and Olms, 1997)], and F. virginiana ssp. virginiana elite clone RH 30 [collected in New York (Hancock et al., 2001)] were dug from the Southwest Michigan Research and Extension Center (Benton Harbor, MI), potted in 3.8-L pots, and grown in a greenhouse at Michigan State University under natural long-day conditions at $23^{\circ} \mathrm{C}$. Developing runner plants were then rooted in $10-\mathrm{cm}$ square pots. After about 4 weeks, the connecting stolons were severed and runner plants were transplanted into 3.8 -L pots filled with soilless media containing (v/v) 70\% peatmoss, $21 \%$ perlite, and $9 \%$ vermiculite (Sure-Mix; Michigan Grower Products, Galesburg, MI). On 25 Oct. 2007, 72 plants consisting of a single crown of each genotype were selected, and any flowers or runners present were removed. On 2 Nov. 2007, 12 plants of each genotype were placed in one of six glass-glazed greenhouses set to a constant temperature of $14,17,20,23,26$, or $29^{\circ} \mathrm{C}$. The air temperature in each treatment was measured by a Type E thermocouple (TT-E-40; Omega Engineering, Stamford, CT) placed in an aspirated tube. Thermocouples were connected to a data logger (CR10; Campbell Scientific, Logan, UT) and data were recorded every $10 \mathrm{~s}$. Weekly averages for each temperature were within $\pm 1.0^{\circ} \mathrm{C}$ of the set point each week during the experimental period. The vapor pressure deficit was calculated by environmental control computer software (Priva North America, Vineland Station, ON, Canada), using wet and dry bulb temperatures, and was maintained between 0.7 and $1.0 \mathrm{kPa}$ at each temperature by steam injection.

Within each temperature treatment, half of the plants were maintained under a 9-h photoperiod (plants were covered with an opaque cloth from 1700 to $0800 \mathrm{HR}$ daily) and half were maintained under a 16-h photoperiod [ambient daylight supplemented with $50 \mu \mathrm{mol} \cdot \mathrm{m}^{-2} \cdot \mathrm{s}^{-1}$ photosynthetically active radiation supplied by high-pressure sodium lamps from 0600 to $2200 \mathrm{HR}$ daily; lamps were programmed to turn off when ambient irradiance outside the greenhouse exceeded 400 $\mu \mathrm{mol} \cdot \mathrm{m}^{-2} \cdot \mathrm{s}^{-1}$; irradiance was measured with line quantum sensors consisting of 10 photodiodes (Apogee Instruments, Logan, UT) connected to a data logger]. Plants were overhead irrigated with reverse osmosis water supplemented with a water-soluble fertilizer to provide the following (in $\mathrm{mg} \cdot \mathrm{L}^{-1}$ ): 125 N, 13 P, $125 \mathrm{~K}, 15 \mathrm{Ca}, 1 \mathrm{Fe}, 0.1 \mathrm{~B}, 0.1 \mathrm{Mo}, 0.5 \mathrm{Mn}, 0.5 \mathrm{Zn}$, and $0.5 \mathrm{Cu}$ (MSU Special; Greencare Fertilizers, Chicago). Moderate nutrient levels were applied as high $\mathrm{N}$ rates are known to reduce yield and delay flowering in strawberry (Voth et al., 1967).

Data Collection and analysis. Every 10 to $15 \mathrm{~d}$ during the experiment, the number of inflorescences per plant, flowers per inflorescence, and runners were determined. Inflorescences were counted once all flower buds within the inflorescence were clearly distinguishable. After each data collection, inflorescences, runners, and any dead leaves were removed. Data collected during the first $49 \mathrm{~d}$ of the experiment were not included in the data analysis, as any flowers or runners appearing during this period were likely initiated before initiation of the experiment (Serçe and Hancock, 2005b). Therefore, only data collected between days 63 and 178 were included for statistical analysis. The experiment employed a split plot design with temperature as the main plot and photoperiod as the subplot, with genotypes randomly assigned within each subplot. Analyses of variance were conducted using PROC GLM in SAS (version 8.2; SAS Institute, Cary, $\mathrm{NC)}$.

\section{Results}

Flowering. Genotype, temperature, and photoperiod interacted to impact the number of inflorescences and total flowers produced (Table 1). RH 30 and 'Tribute' produced inflorescences from about day 28 onward under both photoperiods from 14 to $23{ }^{\circ} \mathrm{C}$ (Fig. 1), with only 'Tribute' producing inflorescences under both photoperiods at $26^{\circ} \mathrm{C}$. Inflorescence production in 'Honeoye' lagged about $84 \mathrm{~d}$ behind RH 30 and 'Tribute' in all temperature and photoperiod treatments where flowering occurred (Fig. 1).

Under long days, 'Honeoye' flower and inflorescence number were greatest at 14 and $17^{\circ} \mathrm{C}$, decreased as temperature increased to $20{ }^{\circ} \mathrm{C}$, with flowering completely inhibited at 26 and $29^{\circ} \mathrm{C}$ (Figs. 1 and 2A). Under short days, 'Honeoye' flower number increased as temperature increased from 14 to $20{ }^{\circ} \mathrm{C}$ (Fig. 2A). Flower number decreased as temperature further increased to 23 or $26^{\circ} \mathrm{C}$, and flowering was inhibited at $29^{\circ} \mathrm{C}$. Under 14 and $17^{\circ} \mathrm{C}$, 'Honeoye' produced more flowers under long days than short days, while under temperatures of 20 to $26{ }^{\circ} \mathrm{C}$, flower production was greater under short days. The genotype RH 30 displayed a similar trend for flower production, producing more flowers per plant under long days than short days at 14 and $17^{\circ} \mathrm{C}$, similar numbers under both photoperiods at $20^{\circ} \mathrm{C}$, and more flowers under short days than long days at 23 to $29^{\circ} \mathrm{C}$ (Fig. 2B). RH 30 was the only genotype to produce flowers under short days at $29{ }^{\circ} \mathrm{C}$, though flowering was minimal. In contrast to 'Honeoye' and RH 30, 'Tribute' produced more flowers under long days than short days, regardless of temperature (Fig. 2C). 'Tribute' was also the only genotype to produce flowers under long days at $29^{\circ} \mathrm{C}$. Flower production in 'Tribute' was similar as the temperature increased from 14 to $23{ }^{\circ} \mathrm{C}$ under long days, but decreased about $30 \%$ as the temperature further increased to 26 or $29^{\circ} \mathrm{C}$.

Differences in flower production could be due to variations in inflorescence production, the number of flowers produced per inflorescence, or both. In general, the differences in flower production observed in this study were more strongly associated with variation in inflorescence number than flowers per inflorescence, as patterns of inflorescence number and flower number were very similar across temperature for each genotype and photoperiod (Fig. 1). This was particularly true at temperatures of $20^{\circ} \mathrm{C}$ or lower. Flower number per inflorescence was similar for 'Honeoye' at temperatures of $20{ }^{\circ} \mathrm{C}$ or less, regardless of photoperiod (Fig. 3A). As temperature increased from 23 to $26{ }^{\circ} \mathrm{C}$, 'Honeoye' flower number per inflorescence decreased from eight to three flowers. RH 30 flower number per inflorescence was similar between 14 and $20^{\circ} \mathrm{C}$ under long

Table 1. Analysis of variance probability values for the impact of genotype (three levels), temperature (five levels), and photoperiod (two levels) on total inflorescences, flowers, and runners produced.

\begin{tabular}{lrrr}
\hline & Inflorescences & Flowers & Runners \\
\cline { 2 - 4 } Source & \multicolumn{3}{c}{ Probability } \\
\hline Genotype (G) & $<0.001$ & $<0.001$ & $<0.001$ \\
Temperature (T) & $<0.001$ & $<0.001$ & $<0.001$ \\
Photoperiod (P) & $<0.001$ & $<0.001$ & $<0.001$ \\
$\mathrm{G} \times \mathrm{T}$ & 0.005 & $<0.001$ & $<0.001$ \\
$\mathrm{G} \times \mathrm{P}$ & $<0.001$ & $<0.001$ & $<0.001$ \\
$\mathrm{~T} \times \mathrm{P}$ & 0.025 & $<0.001$ & $<0.001$ \\
$\mathrm{G} \times \mathrm{T} \times \mathrm{P}$ & 0.002 & $<0.001$ & $<0.001$ \\
\hline
\end{tabular}




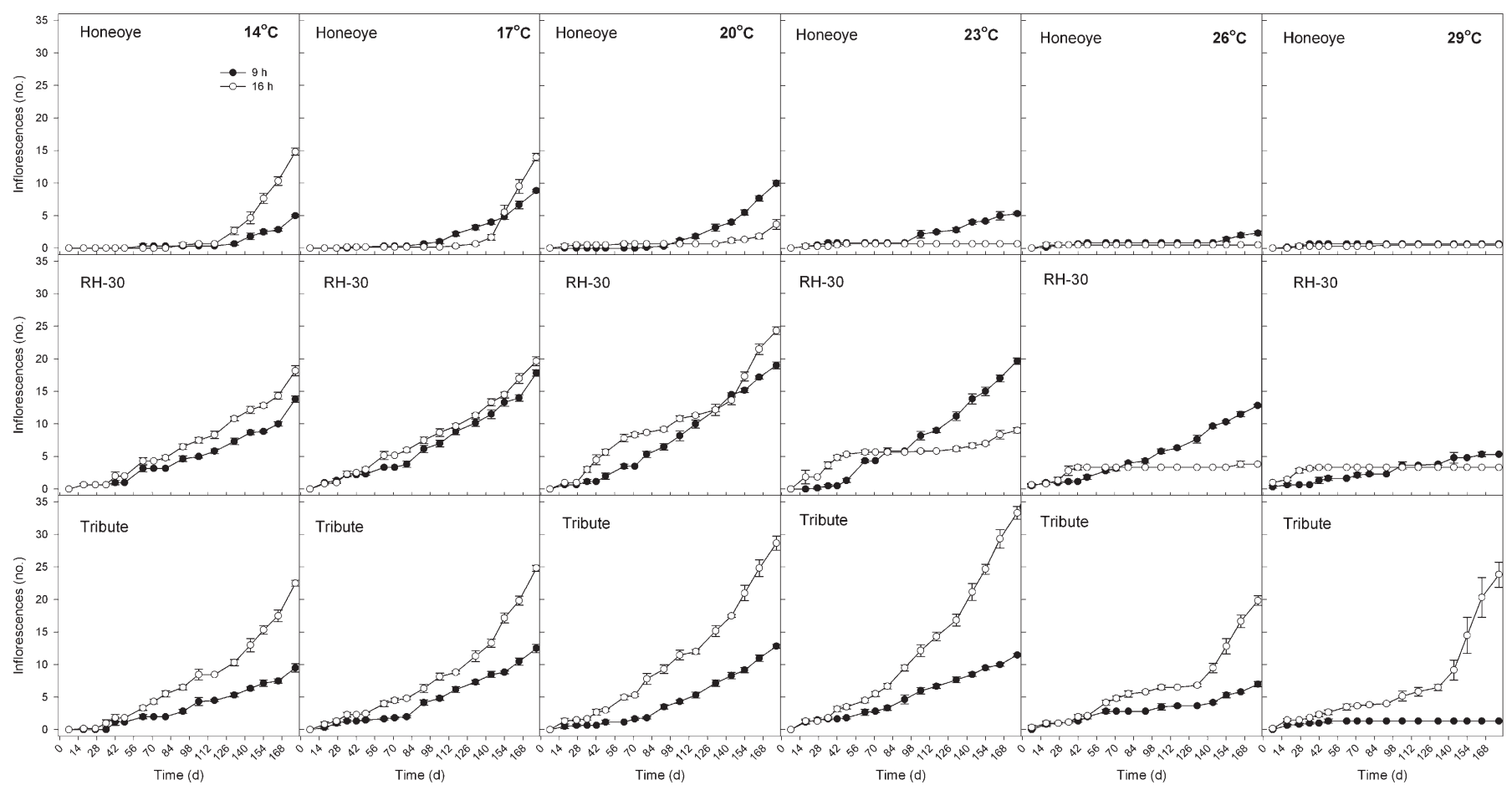

Fig. 1. The effect of temperature on the cumulative number of inflorescences produced for strawberry genotypes 'Honeoye', RH 30, and 'Tribute' under a 9-h (filled circles) or 16-h (empty circles) photoperiod. Error bars represent SE.

days, but decreased as temperature further increased to 23 or $26^{\circ} \mathrm{C}$ (Fig. 3B). Under short days, RH 30 flower number per inflorescence was similar between 14 and $23^{\circ} \mathrm{C}$, decreasing as temperature increased to 26 or $29^{\circ} \mathrm{C}$. At 14 and $17^{\circ} \mathrm{C}$, RH 30 produced more flowers per inflorescence under long days than short days, and more flowers per inflorescence under short days than long days at temperatures of 23 and $26^{\circ} \mathrm{C}$. Under long days, flower number per inflorescence for 'Tribute' was relatively constant across the entire temperature range (Fig. 3C). Under short days, 'Tribute' produced fewer flowers per inflorescence at 26 or $29^{\circ} \mathrm{C}$ than under cooler temperatures.

RunNer PRODUCTION. Temperature, photoperiod, and genotype interacted to influence the number of runners produced (Table 1). 'Honeoye' did not produce runners at 14 or $17^{\circ} \mathrm{C}$, regardless of photoperiod (Fig. 4A). Under short days, 'Honeoye' did not produce runners, regardless of temperature. The number of runners produced increased as temperature increased from 20 to $26^{\circ} \mathrm{C}$, but declined as temperature increased from 26 to $29^{\circ} \mathrm{C}$ (Fig. 4A). In contrast to 'Honeoye,' RH 30 did produce runners under short days, but only at temperatures of 23 to $29^{\circ} \mathrm{C}$ (Fig. 4B). Runner production for RH 30 increased with temperature from 14 to $29^{\circ} \mathrm{C}$ under long days. RH 30 produced far more runners than either cultivar under long days and temperatures $\geq 20^{\circ} \mathrm{C}$. The cultivar 'Tribute' produced very few runners under short days, and only if temperatures were $23^{\circ} \mathrm{C}$ or greater (Fig. $4 \mathrm{C})$. Runner production for 'Tribute' under long days was lower than 'Honeoye' or RH 30 at temperatures $\geq 23{ }^{\circ} \mathrm{C}$, with a maximum of seven runners per plant produced at $23^{\circ} \mathrm{C}$.

\section{Discussion}

Strawberry cultivars vary greatly in the expression of remontancy in temperate climates. We have evaluated flower- ing of two $F$. Xananassa cultivars and one $F$. virginiana ssp. virginana genotype exhibiting contrasting flowering patterns in response to temperature and photoperiod. Our results suggest that the observed differences in flowering patterns in the field between strawberry genotypes arise from 1) variations in temperature tolerance, photoperiod-independent and photoperiod-dependent, 2) differential photoperiodic responses if temperatures exceed the photoperiod-insensitive temperature range, and 3) the rate of development toward flowering. Together, these results indicate that photoperiodic classifications alone are inadequate to describe the expression of remontancy in strawberry, and screening for "day neutrality" in cool temperate regions may not translate into development of cultivars that exhibit remontancy in warmer regions.

Each genotype exhibited a temperature range where flowering occurred under long and short photoperiods, and the response varied by genotype (Fig. 1). The permissive temperature range for remontancy under both photoperiods was up to $20{ }^{\circ} \mathrm{C}$ for 'Honeoye', $23{ }^{\circ} \mathrm{C}$ for $\mathrm{RH} 30$, and $26^{\circ} \mathrm{C}$ for 'Tribute'. In addition to the contrasting temperature ranges where flowering occurred under both photoperiods, 'Tribute' and 'Honeoye' exhibited contrasting photoperiod requirements if temperature exceeded this range. 'Tribute' responded as a qualitative (obligate) long-day at $29^{\circ} \mathrm{C}$ and a quantitative (facultative) long-day plant at lower temperatures, similar to results for a selection of "everbearing" cultivars described previously (Nishiyama and Kanahama, 2000; Sønsteby and Heide, 2007). RH 30 was previously defined as "day neutral" (Serçe and Hancock, 2005a). However, in the current study, 'Honeoye' and RH 30 responded as qualitative short-day plants at 23 and $26{ }^{\circ} \mathrm{C}$, respectively, and generally photoperiod insensitive at lower temperatures. The response of RH 30 is somewhat in contrast to results of Sønsteby and Heide (2008), who classified 


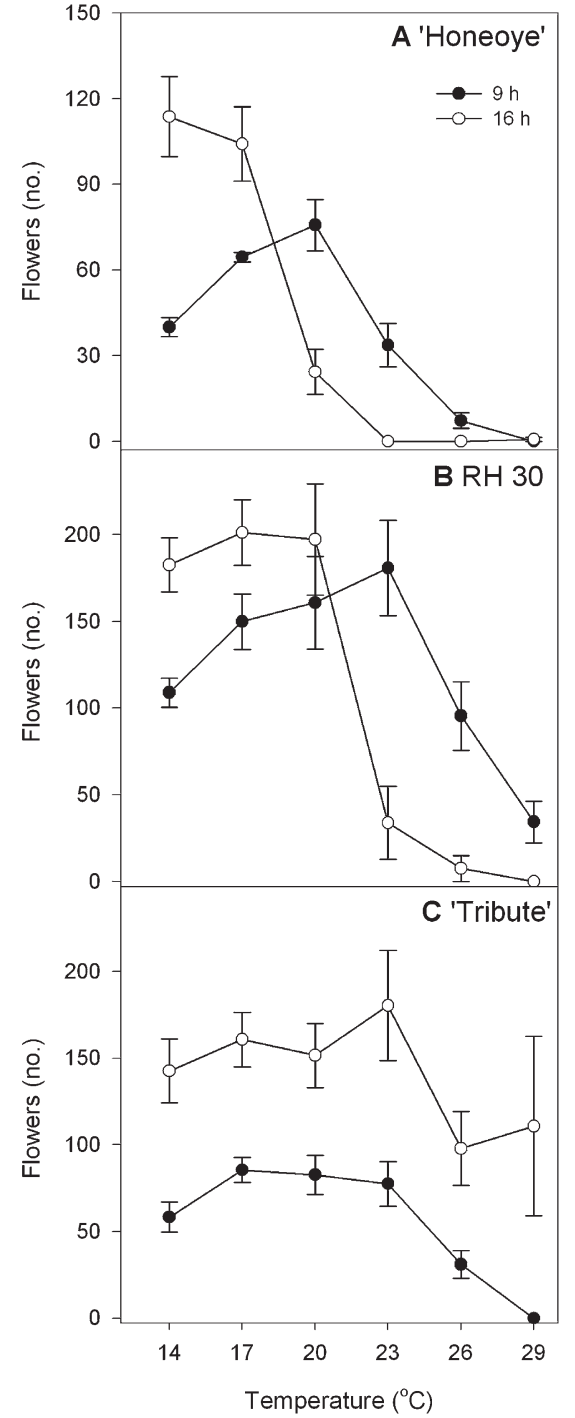

Fig. 2. The effect of temperature on the number of flowers produced for strawberry genotypes (A) 'Honeoye', (B) RH 30, and (C) 'Tribute' under a 9-h (filled circles) or 16-h (empty circles) photoperiod during a 16-week period (days 63-178). Error bars represent SE.

three other $F$. virginiana ssp. virginiana populations as quantitative short-day plants. For 'Honeoye' and RH 30, however, growing plants under short days only improved temperature tolerance for flowering by $3{ }^{\circ} \mathrm{C}$. For 'Honeoye', plants produced few or no inflorescences at temperatures of 26 and $29^{\circ} \mathrm{C}$, regardless of photoperiod. The temperature threshold for flowering of 'Tribute' under long days was not established, as plants continued to flower strongly at $29{ }^{\circ} \mathrm{C}$, the highest temperature evaluated.

Further support for the importance of temperature on remontancy in strawberry comes from a quantitative trait locus (QTL) analysis for remontancy using phenotypic data for a 'Honeoye' $x$ 'Tribute' mapping population grown at five different locations throughout the United States (Weebadde et al., 2008). Runner plants of the same genotypes were grown in California (Watsonville), Maryland (Beltsville), Michigan (Benton Harbor), Minnesota (Victoria), and Oregon (Corvallis) for phenotypic analysis. The percentage of remontant individ-

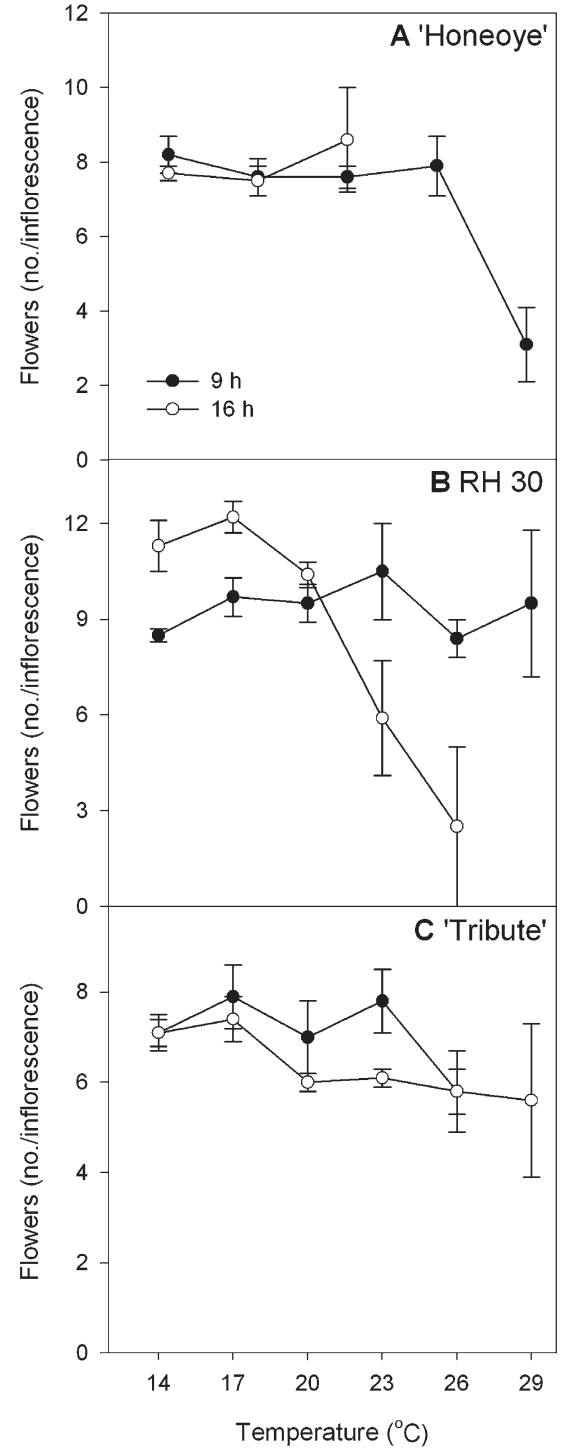

Fig. 3. The effect of temperature on the number of flowers per inflorescence for strawberry genotypes (A) 'Honeoye', (B) RH 30, and (C) 'Tribute' under a 9-h (filled circles) or 16-h (empty circles) photoperiod during a 16-week period (days 63-178). Error bars represent SE.

uals varied by location, with $48 \%$ to $50 \%$ of plants repeat flowering in the Maryland, Michigan, and Minnesota locations, $80 \%$ in Oregon, and $87 \%$ in California. The latitudinal range covered by the three eastern U.S. locations is similar to that of the California and Oregon sites, indicating that differences in photoperiod alone cannot explain the observed differences in flowering. However, weather station data from each location indicated that the California and Oregon sites were considerably cooler (day and night temperatures) than any of the eastern sites. A QTL explaining 36\% of the phenotypic variation for remontancy identified in the Maryland, Michigan, and Minnesota populations, but not in California or Oregon, was hypothesized as a potential locus for heat tolerance. The identification of permissive and inhibitive temperatures for repeat flowering of 'Honeoye' and 'Tribute' will allow us to test this hypothesis using the same 'Tribute' $\times$ 'Honeoye' population in controlled environments. 


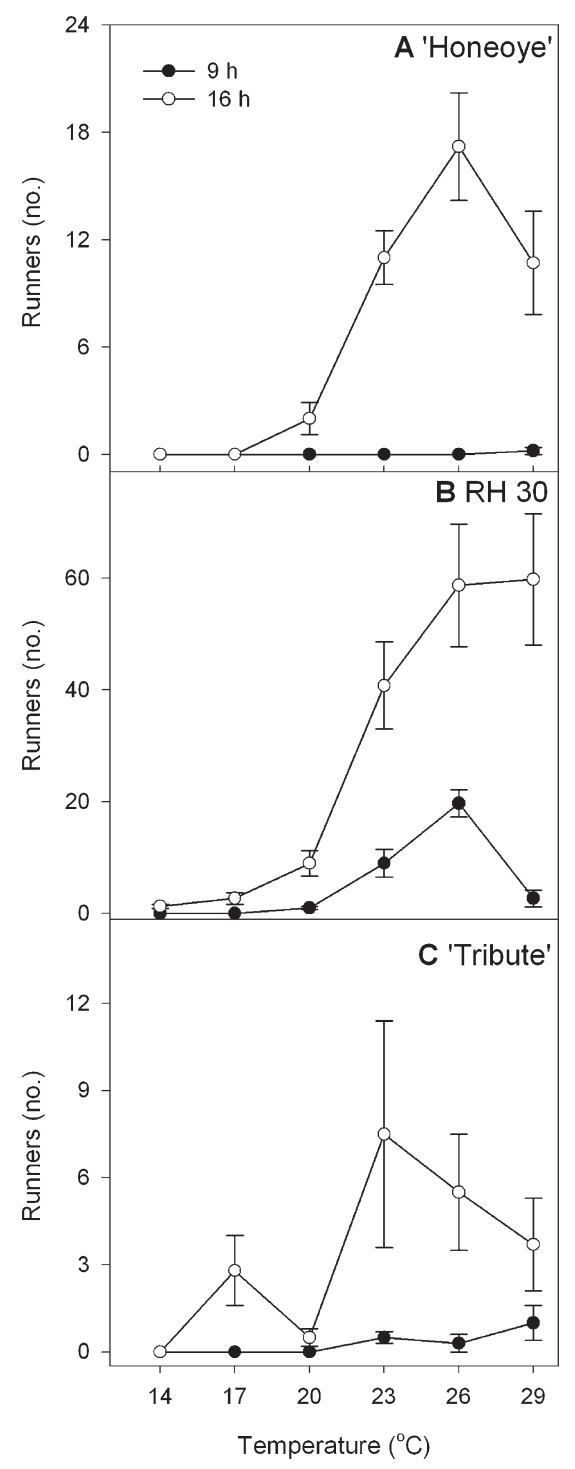

Fig. 4. The effect of temperature on the number of runners per plant for strawberry genotypes (A) 'Honeoye', (B) RH 30, and (C) 'Tribute' under a 9-h (filled circles) or 16-h (empty circles) photoperiod during a 16-week period (days 63-178). Error bars represent SE.

It is not known whether the reduction/inhibition of flowering at high temperatures is due to a lack of floral initiation or to a failed development of an initiated inflorescence before macroscopic visibility. Taylor (2002) suggested that flowering inhibition of mature strawberry plants may be due to early developmental arrest of initiated flowers rather than failed initiation, and that microscopic dissection should be conducted in addition to counting inflorescences to describe meristem fate. In support of this are the results of Downs and Piringer (1955) who, in a summer experiment in Beltsville, MD, using a greenhouse lacking temperature control, reported the presence of flower primordia following dissection but no macroscopic flower buds on two Junebearing genotypes, Howard 17 and Klondike, under an 11-h photoperiod. These results suggest that high temperatures prevented floral development even under short-day conditions.

Another factor that appears to influence the expression of remontancy is the rate of floral initiation and/or development.
'Honeoye' flowered considerably later than 'Tribute' or RH 30 in all temperature/photoperiod combinations where flowering occurred. The slow rate of development toward flowering of 'Honeoye' may be common among Junebearing genotypes. Nicoll and Galletta (1987) reported that the rate of meristem development, defined as the sum of axillary buds that emerged as branch crowns, runners, or inflorescences, for the Junebearing genotype MDUS 4355 was much lower than any of eight genotypes exhibiting variable remontant strength, despite having similar or faster rates of leaf production. Furthermore, Barritt et al. (1982) reported, using DN and SD cultivars bred in California, Oregon, and Washington, that DN progeny of crosses among DN parents flowered earlier than DN progeny of crosses between SD parents. This is consistent with observations that Junebearing cultivars do not express remontancy in the relatively short growing seasons of temperate climates, even when summer temperatures are cool. This may also explain the inconsistent expression of remontancy of RH 30derived genotypes across years, exhibiting strong remontancy some years, while only flowering in the Spring of other years (J.F. Hancock, unpublished data). Although RH 30 and 'Honeoye' exhibited similar photoperiodic responses, the slightly higher temperature tolerance and faster development rate of RH 30 may allow remontancy during cooler summers in temperate climates.

Runner formation was photoperiod and temperature sensitive, consistent with previous studies, indicating that runner formation is stimulated by high temperatures and long days (Darrow, 1936; Durner et al., 1984; Heide, 1977). Runners were only formed under long days in 'Honeoye' and 'Tribute' (Fig. 4). Similarly, Serçe and Hancock (2005b) did not observe runner development under 12-h days, regardless of temperature. RH 30 did produce runners under short days at 23 and $26^{\circ} \mathrm{C}$; however, runner production was greatly reduced compared with long days at similar temperatures. The inhibition of runner formation under short photoperiods appears to be related to gibberellin metabolism. Hytönen et al. (2009) determined that the SD strawberry 'Korona' formed branch crowns but not runners under a 10 - or $14-\mathrm{h}$ photoperiod $\left(18 / 15^{\circ} \mathrm{C}\right.$ day/night in all photoperiods), and formed runners under an 18-h photoperiod. This corresponded to reduced concentration of the active gibberellin $\mathrm{GA}_{1}$ in axillary buds of plants exposed to short photoperiods. Branch crown formation was promoted under an 18-h photoperiod following application of the gibberellin synthesis inhibitor prohexadione-calcium. Subsequent $\mathrm{GA}_{3}$ application restored the development of runners and inhibition of branch crown formation. Application of $\mathrm{GA}_{3}$ marginally promoted runner formation under short days, though to a lesser extent than long-day exposure, indicating an additional role for photoperiod beyond GA metabolism in vegetative meristem differentiation. Our results suggest that, for the genotypes evaluated in this study under our experimental conditions, flowering inhibits the formation of runners, and that flowering is primarily controlled by temperature. If temperature is inhibitive for flowering, runner formation is then promoted in a photoperiod-dependent manner.

In conclusion, our results indicate that temperature plays a major role in determining remontancy in strawberry, and that classifying genotypes into photoperiodic classes alone inadequately describes the environmental influence on this trait. The complexity of environmental influence on the expression of remontancy helps explain why the genetics of remontancy in 
strawberry have proven difficult to dissect, with contrasting reports of whether this trait is controlled by a single dominant gene (Ahmadi et al., 1990; Bringhurst and Voth, 1978), complimentary dominant genes (Ourecky and Slate, 1967), or is quantitatively inherited (Hancock et al., 2002; Powers, 1954; Serçe and Hancock, 2005a; Shaw, 2003; Weebadde et al., 2008). Our results suggest that the lack of remontant habit among Junebearing genotypes may be the result of three factors: 1) a narrower photoperiod-insensitive temperature range compared with remontant genotypes, 2) an obligate short-day requirement if temperatures exceed the photoperiod-insensitive range, and 3) a slower rate of floral initiation/development in environments conducive to flowering. Evaluating an expanded selection of 'Junebearing' and remontant cultivars will determine if the responses observed here are representative of cultivars in these response groups.

\section{Literature Cited}

Ahmadi, H., R.S. Bringhurst, and V. Voth. 1990. Modes of inheritance of photoperiodism in Fragaria. J. Amer. Soc. Hort. Sci. 115:146152.

Barritt, B.H., R.S. Bringhurst, and V. Voth. 1982. Inheritance of early flowering in relation to breeding day-neutral strawberries. J. Amer. Soc. Hort. Sci. 107:733-736.

Bringhurst, R.S. and V. Voth. 1978. Origin and evolutionary potentiality of the day-neutral trait in octoploid Fragaria. Genetics 90:510. (Abstr.).

Brooks, R.M. and H.P. Olms. 1997. Register of fruit and nut varieties. 3rd ed. ASHS Press, Alexandria, VA.

Darrow, G.M. 1936. Interrelation of temperature and photoperiodism in the production of fruit-buds and runners in the strawberry. Proc. Amer. Soc. Hort. Sci. 34:360-363.

Darrow, G.M. and G.F. Waldo. 1934. Responses of strawberry varieties and species to duration of the daily light period. U.S. Dept. Agr. Tech. Bul. 453.

Downs, R.J. and A.A. Piringer. 1955. Differences in photoperiodic responses of everbearing and June-bearing strawberries. Proc. Amer. Soc. Hort. Sci. 66:234-236.

Draper, A.D., G.J. Galletta, and H.J. Swartz. 1981. 'Tribute' and 'Tristar' everbearing strawberries. HortScience 16:794-795.

Durner, E.F., J.A. Barden, D.G. Himelrick, and E.B. Poling. 1984. Photoperiod and temperature effects on flower and runner development in day-neutral, Junebearing, and everbearing strawberries. J. Amer. Soc. Hort. Sci. 109:396-400.

Guttridge, G.C. 1985. Fragaria ×ananassa, p. 16-33. In: A.H. Halevy (ed.). CRC handbook of flowering. Vol. 3. CRC Press, Boca Raton, FL.

Hancock, J.F., J.J. Luby, A. Dale, P.W. Callow, S. Serçe, and A. ElShiek. 2002. Utilizing wild Fragaria virginiana in strawberry cultivar development: Inheritance of photoperiod sensitivity, fruit size, gender, female fertility and disease resistance. Euphytica 126:177-184.
Hancock, J.F., P.W. Callow, A. Dale, J.J. Luby, C.E. Finn, S.C. Hokanson, and K.E. Hummer. 2001. From the Andes to the Rockies: Native strawberry collection and utilization. HortScience 36:221225.

Heide, O.M. 1977. Photoperiod and temperature interactions in growth and flowering of strawberry. Physiol. Plant. 40:21-26.

Hytönen, T., P. Elomaa, T. Moritz, and O. Junttila. 2009. Gibberellin mediates daylength-controlled differentiation of vegetative meristems in strawberry (Fragaria $\times$ ananassa Duch.). BMC Plant Biol. 9:18, doi: 10.1186/1471-2229-9-18.

Ito, H. and T. Saito. 1962. Studies on the flower formation in the strawberry plants. I. Effects of temperature and photoperiod on the flower formation. Tohoku J. Agr. Res. 13:191-203.

Nicoll, M.F. and G.J. Galletta. 1987. Variation in growth and flowering habits of June-bearing and everbearing strawberries. J. Amer. Soc. Hort. Sci. 112:872-880.

Nishiyama, M. and K. Kanahama. 2000. Effect of temperature and photoperiod on the development of inflorescences in everbearing strawberry (Fragaria $\times$ ananassa Duch.) plants. Acta Hort. 514:261267.

Ourecky, D.K. and D.L. Slate. 1967. Behavior of the everbearing characteristics in strawberries. J. Amer. Soc. Hort. Sci. 91:236-241.

Powers, L. 1954. Inheritance of period of blooming in progenies of strawberries. Proc. Amer. Soc. Hort. Sci. 64:293-298.

Serçe, S. and J.F. Hancock. 2005a. Inheritance of day-neutrality in octoploid species of Fragaria. J. Amer. Soc. Hort. Sci. 130:580-584.

Serçe, S. and J.F. Hancock. 2005b. The temperature and photoperiod regulation of flowering and runnering in the strawberries, Fragaria chiloensis, F. virginiana, and F. ×ananassa. Scientia Hort. 103:167177.

Shaw, D.V. 2003. Heterogeneity of segregation ratios from selfed progenies demonstrate polygenic inheritance for day neutrality in strawberry (Fragaria ×ananassa Duch.). J. Amer. Soc. Hort. Sci. 128:504-507.

Shaw, D.V. and T.R. Famula. 2005. Complex segregation analysis of day-neutrality in domestic strawberry (Fragaria $\times$ ananassa Duch.). Euphytica 145:331-338.

Sønsteby, A. and O.M. Heide. 2007. Long-day control of flowering in everbearing strawberries. J. Hort. Sci. Biotechnol. 82:875-884.

Sønsteby, A. and O.M. Heide. 2008. Flowering physiology of populations of Fragaria virginana. J. Hort. Sci. Biotechnol. 83: 641-647.

Sugimoto, T., K. Tamaki, Y. Matsumoto, K. Shiwaku, and K. Watanabe. 2005. Detection of RAPD markers linked to the everbearing gene in Japanese cultivated strawberry. Plant Breed. 124: 498-501.

Taylor, D.R. 2002. The physiology of flowering strawberries. Acta Hort. 567:245-251.

Voth, V., K. Urin, and R.S. Bringhurst. 1967. Effect of high nitrogen applications on yield, earliness, fruit quality and leaf composition of California strawberries. Proc. Amer. Soc. Hort. Sci. 91:249-256.

Weebadde, C.K., D. Wang, C.E. Finn, K.S. Lewers, J.J. Luby, J. Bushakra, T.M. Sjulin, and J.F. Hancock. 2008. Using a linkage mapping approach to identify QTL for day-neutrality in the octoploid strawberry. Plant Breed. 127:94-101. 